\title{
PHENOLSULPHONPHTHALEIN CLEARANCE FROM THE KNEE JOINT IN NORMAL AND PATHOLOGICAL STATES
}

\author{
BY \\ R. NAKAMURA, H. ASAI, H. SONOZAKI, AND M. NAGANO \\ Department of Orthopaedic Surgery, Faculty of Medicine, University of Tokyo, Tokyo, Japan
}

Phenolsulphonphthalein (PSP) clearance from the joint has been shown to be a reliable method of measuring the permeability of synovial membrane (Bianchi, 1953; Seifter and Baeder, 1954), and has been used to study the anti-inflammatory effect of various drugs in experimental animals (Seifter, Baeder, and Begary, 1949; Bianchi, 1953; Sharp, 1963). Moreover, the clearance of radioactive substances has been studied in patients with arthritis to ascertain local disease activity and the effect of intra-articular injections of corticosteroids (Ahlström, Gedda, and Hedberg, 1965; Davison and Wisham, 1958; Harris, Millard, and Banerjee, 1958; Scholer, Lee, and Polley, 1959). Nevertheless, the clinical application of such studies is still a matter of debate (Seifter and Baeder, 1954; Harris and others, 1958).

We have used the PSP clearance technique to study the knee joint in normal subjects and in various types of arthritis. We attempted to establish a standard method for measuring the clearance rate and to analyse the factors which might influence the rate.

\section{Material andi Methods}

Our subjects were 31 normal adults (18 ambulant and 13 bed-ridden: age range 18 to 54 years); there were nine with rheumatoid arthritis, twenty with osteo-arthritis, two with acute traumatic haemarthrosis, four with meniscus injury, one with Charcot joint, and one with acute infective arthritis. They all had normal renal function. Thirteen normal and three osteo-arthritic persons were confined to bed for more than a week.

The PSP clearance rate was assessed in terms of the urinary dye excretion rate.

Before the test the subjects were resting in bed or sitting comfortably for at least 30 minutes. All experiments were carried out at room temperatures of $20^{\circ}$ to $25^{\circ} \mathrm{C}$. The bladder was emptied before the injection of $1 \mathrm{ml}$. PSP into the knee joint. If effusion was present the PSP was injected after withdrawing the fluid. Urine was collected 30 minutes, and 1, 2, 3, and 4 hours after the injection.

PSP in the urine was estimated by colorimetric comparison with the standard solution of dye after the full colour development with sodium hydroxide solution and the dilution with water. A photo-electric colorimeter (Klett-Summerson) and filter at $540 \mathrm{~m} \mu$ was used.

In two normal subjects $1 \mathrm{ml}$. PSP with $20 \mathrm{ml}$. saline was injected and $0.2 \mathrm{ml}$. intra-articular fluid was withdrawn at hourly intervals after the injection for 4 hours. The $\omega$ PSP excreted and that remaining in the knee joint was compared.

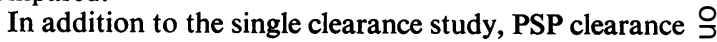
measurements were repeated in the osteo-arthritic patients after the intra-articular injection of $25 \mathrm{mg}$. prednisolone $\bar{z}$ acetate and with a hot pack applied locally around the knee joint (skin temperature $40^{\circ}$ to $43^{\circ} \mathrm{C}$ ).

The degree of disease activity and that of effusion present in the knee joint were graded from 0 to 3; this. gradation is slightly modified from that of Harris and others (1958):

\section{Disease Activity:}

$0=$ None.

$1=$ Minor (Heat - ; Tenderness \pm ; Pain at rest - ; Pain on use \pm ).

$2=$ Moderate (Heat \pm ; Tenderness + ; Pain at rest \pm ; Pain on use + ).

$3=$ Severe (Heat + ; Tenderness + ; Pain at rest \pm ; Pain on use + ).

\section{Effusion:}

$0=$ None.

$1=$ Just perceptible.

$2=$ Moderate.

$3=$ Large.

\section{Results}

\section{Normal Subjects}

The results in eighteen normal ambulant and $\stackrel{N}{\sigma}$ physically active subjects are presented in Table I.

TABLE I

PSP CLEARANCE RATE IN EIGHTEEN NORMAL SUBJECTS WITHOUT KNEE INVOLVEMENT

\begin{tabular}{l|c|c|c}
\hline \multicolumn{1}{c|}{ Time } & Range & Mean & $\begin{array}{c}\text { Standard } \\
\text { Deviation }\end{array}$ \\
\hline $30 \mathrm{~min}$. & $0 \cdot 6-12 \cdot 4$ & $6 \cdot 4$ & $\overline{5}$ \\
$1 \mathrm{hr}$ & $4 \cdot 8-24 \cdot 0$ & $13 \cdot 4$ & $5 \cdot 9$ \\
$2 \mathrm{hrs}$ & $8 \cdot 8-32 \cdot 0$ & $22 \cdot 7$ & $5 \cdot 8$ \\
$3 \mathrm{hrs}$ & $24 \cdot 1-37 \cdot 8$ & 30.9 & $4 \cdot 2$ \\
$4 \mathrm{hrs}$ & $32 \cdot 8-48 \cdot 1$ & $41 \cdot 3$ & $5 \cdot 4$ \\
\hline
\end{tabular}


The standard deviation was least 3 hours after the injection. The correlation between the PSP excreted in urine and remaining in the knee joint is shown in Fig. 1; this was best at 3 hours. From these data we took the amount of dye excreted at 3 hours after the injection as the clearance rate; the normal values were thus $30 \cdot 3$ (mean) $\pm 4 \cdot 2$ (s.d.).

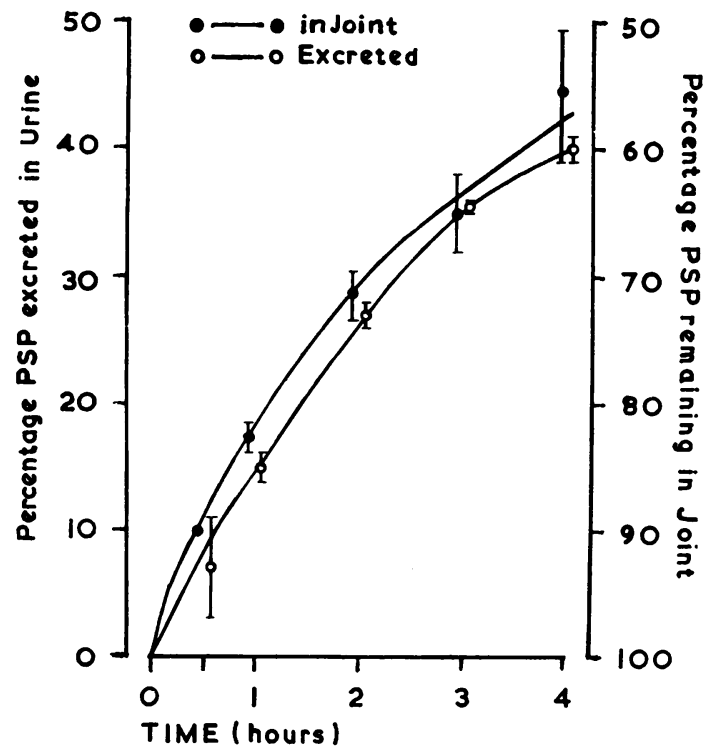

Fig. 1.-Correlation between urinary excretion of PSP and PSP remaining in joint.

The clearance rate in the thirteen normal subjects who were confined to bed for more than a week was significantly higher $-49 \cdot 3 \pm 5 \cdot 7$ (Table II).

TABLE II

PSP CLEARANCE RATE IN THIRTEEN BED-RIDDEN SUBJECTS WITHOUT KNEE INVOLVEMENT

\begin{tabular}{l|c|c|c}
\hline \multicolumn{1}{c|}{ Time } & Range & Mean & $\begin{array}{c}\text { Standard } \\
\text { Deviation }\end{array}$ \\
\hline $30 \mathrm{~min}$. & $\begin{array}{r}0 \cdot 5-20 \cdot 2 \\
13 \cdot 5-36 \cdot 6\end{array}$ & $\begin{array}{r}9 \cdot 7 \\
25 \cdot 8\end{array}$ \\
$2 \mathrm{hr}$ & $29 \cdot 3-50 \cdot 6$ & $40 \cdot 7$ & $6 \cdot 9$ \\
$3 \mathrm{hrs}$ & $41 \cdot 4-57 \cdot 0$ & $49 \cdot 3$ & $6 \cdot 7$ \\
$4 \mathrm{hrs}$ & $47 \cdot 0-67 \cdot 8$ & $56 \cdot 6$ & $5 \cdot 7$ \\
\hline
\end{tabular}

\section{Pathological Cases}

The clearance rate measured in normal and pathological subjects 1,2 , and 3 hours after the injection is shown in Fig. 2 (overleaf). The clearance rates 3 hours after injection in the various patients were compared with the normal values.

Rheumatoid Arthritis.-A high clearance rate was observed in patients with severe local inflammation in the acute stage. In the chronic state the rate was not so high, though synovial hypertrophy and joint effusion were present with mild or moderate inflammation (Table III).

TABLE III

PSP CLEARANCE RATE 3 HOURS AFTER THE INJECTION IN VARIOUS PATHOLOGICAL STATES (17 CASES)

\begin{tabular}{l|l|c|c|c}
\hline \multicolumn{1}{c|}{ Disease } & $\begin{array}{c}\text { No. of } \\
\text { Cases }\end{array}$ & Range & Mean \\
\hline $\begin{array}{l}\text { Rheumatoid } \\
\text { Arthritis }\end{array}$ & Acute & 5 & $42 \cdot 5-58 \cdot 3$ & $50 \cdot 4$ \\
\cline { 2 - 5 } Traumatic Haemarthrosis & 4 & $27 \cdot 0-35 \cdot 6$ & $32 \cdot 3$ \\
\hline $\begin{array}{l}\text { Meniscus } \\
\text { Injury }\end{array}$ & $\begin{array}{l}\text { With quadriceps } \\
\text { atrophy }\end{array}$ & 2 & $46 \cdot 5-47 \cdot 0$ & $46 \cdot 8$ \\
\hline $\begin{array}{l}\text { Without quadriceps } \\
\text { atrophy }\end{array}$ & 2 & $41 \cdot 0-43 \cdot 8$ & $42 \cdot 4$ \\
\hline Charcot Joint & 1 & - & $76 \cdot 0$ \\
\hline Infective Arthritis & 1 & - & $46 \cdot 5$ \\
\hline
\end{tabular}

Acute Traumatic Haemarthrosis.-The rate was moderately elevated in both cases (Table III).

Meniscus Injury.-The rate significantly increased in two cases with marked quadriceps atrophy and slightly in two cases with slight atrophy. Disease activity was Grade 1 or 2 in all four cases. The increased clearance rate was related to the quadriceps atrophy (Table III).

Charcot Joint (caused by tabes dorsalis).-There was a very high clearance rate with severe joint destruction and Grade 3 effusion (Table III).

Infective Arthritis.-Acute Grade 3 suppurative arthritis due to Staphylococcus infection was accompanied by a moderately increased clearance rate (Table III).

Osteo-arthritis.-In all cases tested the clearance rate was higher than normal; the clinical symptoms varied from slight pain on use to moderate pain at rest (Grade 1 to 3). The clearance rate was related to the degree of disease activity (Table IV), i.e. the higher the rate the severer the local inflammatory signs.

TABLE IV

PSP CLEARANCE RATE IN 20 CASES OF OSTEO-ARTHRITIS, BY DISEASE ACTIVITY

\begin{tabular}{c|c|c|c}
\hline $\begin{array}{c}\text { Grade of Disease } \\
\text { Activity }\end{array}$ & $\begin{array}{c}\text { No of } \\
\text { Cases }\end{array}$ & Range & Mean \\
\hline 1 & 6 & $47 \cdot 5-52 \cdot 5$ & $49 \cdot 6$ \\
2 & 9 & $56 \cdot 2-66 \cdot 0$ & $58 \cdot 8$ \\
3 & 5 & $71 \cdot 6-85 \cdot 0$ & $77 \cdot 3$ \\
\hline
\end{tabular}

However, there was no marked correlation between the clearance rate and the presence of effusion (Table V, overleaf).

The clearance rate was significantly reduced 1 or 2 days after the intra-articular injection of $25 \mathrm{mg}$. 


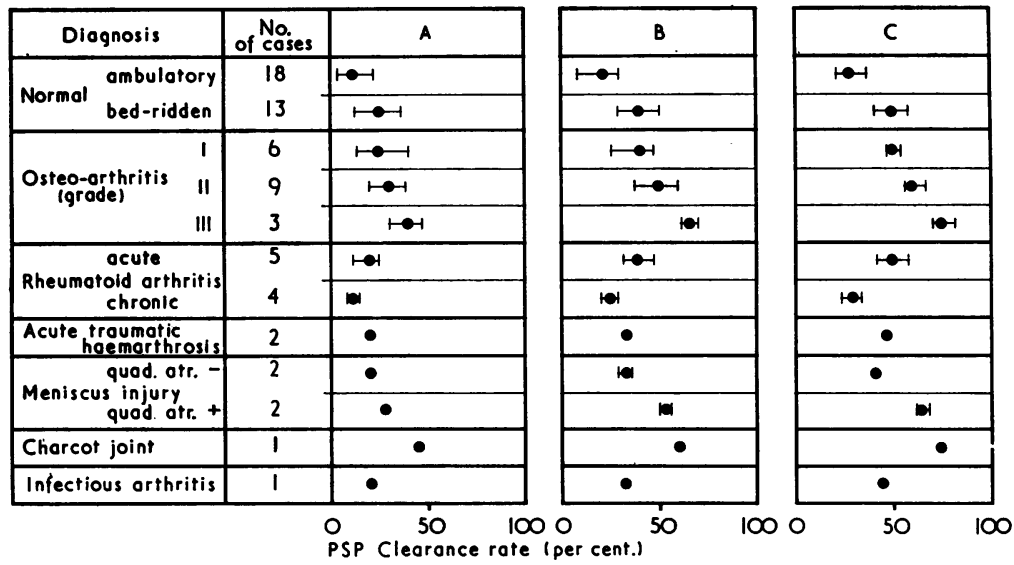

Fig. 2.-Clearance rate in normal and pathological states A : $1 \mathrm{hr}$ after injection B : 2 hrs

TABLE V

PSP CLEARANCE IN 20 CASES OF OSTEO-ARTHRITIS, BY DEGREE OF EFFUSION

\begin{tabular}{c|c|c|c}
\hline Grade of Effusion & $\begin{array}{c}\text { No of } \\
\text { Cases }\end{array}$ & Range & Mean \\
\cline { 1 - 2 } & 3 & $49 \cdot 0-62 \cdot 5$ & $54 \cdot 7$ \\
2 & 6 & $56 \cdot 2-81 \cdot 5$ & $63 \cdot 2$ \\
3 & 11 & $47 \cdot 5-85 \cdot 0$ & $61 \cdot 8$ \\
\hline
\end{tabular}

prednisolone acetate in seven subjects with osteoarthritis (Table VI).

TABLE VI

REDUCTION OF CLEARANCE RATE 1 OR 2 DAYS AFTER INTRA-ARTICULAR INJECTION OF $25 \mathrm{mg}$. PREDNISOLONE ACETATE IN SEVEN CASES OF OSTEO-ARTHRITIS

\begin{tabular}{c|c|c|c}
\hline Case No & Before & After & Difference \\
\hline 1 & 81.5 & 65.8 & $-15 \cdot 7$ \\
2 & 74.0 & 56.0 & -18.0 \\
3 & 61.6 & 48.6 & -13.0 \\
4 & 51.1 & 40.0 & -11.1 \\
5 & 63.1 & 45.5 & -17.6 \\
6 & 66.0 & 56.4 & -9.6 \\
7 & 59.0 & 49.0 & -10.0 \\
\hline
\end{tabular}

The rate also decreased when a hot pack was applied locally to the knee joint during the test in one normal and two osteo-arthritic knee joints (Table VII).

TABLE VII

REDUCTION OF CLEARANCE RATE BY LOCAI APPLICATION OF HOT PACK TO KNEE JOINT IN THREE CASES DURING THE TEST

\begin{tabular}{l|c|c|c}
\hline \multicolumn{1}{c|}{ Diagnosis } & Before & After & Difference \\
\hline Osteo-arthritis & 51.1 & 28.6 & -22.5 \\
& 49.0 & 37.8 & $-11 \cdot 2$ \\
\hline Normal & 38.4 & 14.6 & -23.8 \\
\hline
\end{tabular}

\section{Discussion}

These findings indicate that a moderate variation in clearance rate is observed even in normal subjects, and that the rate increases significantly in pathological states, except rheumatoid arthritis in the chronic stage. According to Barnett, Davies, and MacConaill (1961), Fletcher and his colleagues (1955), using radioactive sodium, demonstrated a variation in the clearance rate in human subjects from day to day. The clearance rate in normal subjects increased after they had been confined to bed for more than a week, when there was no pain or inflammation. This increased clearance rate was presumably due to the increased local blood flow, as has been shown in other tissues (Ferguson, Vaughan, and Ward, 1957; Schröder and Seyfarth, 1960; Udagawa, 1964). Ferguson and Akahoshi (1960) reported that the changes in vascular pattern noted in the rabbit after immobilization in plaster are dilatation of the main arteries and increased vascularization about the knee and ankle. Thus, the increased rate of blood flow may be related to the state of the vascular bed and the sympathetic nervous system.

An increased clearance rate is also seen in cases of acute inflammation; in chronic inflammation the rate is variable, and in cases of severe quadriceps atrophy it is high. This means that in chronic arthritis the local inflammation, though severe, has little effect on PSP clearance, whereas physical inactivity with quadriceps atrophy greatly increases it. This agrees with the higher rate seen in normal subjects who had been confined to bed for more than a week. 
The clearance rate thus depends chiefly on two factors:

(1) Daily physical activity which changes local blood flow;

(2) Local inflammation which modifies both the local blood flow and the permeability of the synovial membrane.

Hence the good correlation in cases of osteoarthritis between the clearance rate and the degree of disease activity. In osteo-arthritic patients physical inactivity is accompanied by muscle weakness and synovitis, which increases the local blood flow and the permeability of the synovial membrane.

The intra-articular injection of corticosteroids on the other hand produced a fall in the clearance rate, a process similar to that observed by other workers (Seifter and others, 1949; Ahlström and others, 1956; Harris and others, 1958; Scholer and others, 1959). According to Sharp (1963), this is clear evidence of an association between the disease and increased permeability and between corticosteroids and decreased permeability. However, the reduction of inflammation by the steroid injection should decrease not only the permeability but also the local blood flow.

The decrease in clearance rate caused by the local hot pack is due to the reduction in blood flow caused by the reflex vasoconstriction in the knee joint. This reflex is also observed in normal subjects. Davison and Wisham (1958) reported that the clearance of radio-sodium from normal joint was accelerated by intra-arterial Priscoline, but the higher rate of clearance from osteoarthritic joints is unaffected, indicating that vasodilation is already present in the synovial vessels.

More attention should be given to the neurovascular reflex mechanism which induces vasodilation and increased local blood flow in the joint, and further study of the factors influencing the clearance rate are also needed.

\section{Summary}

(1) Phenolsulphonphthalein clearance from the knee joint was studied in 31 normal subjects and 37 subjects with pathological conditions of the knee.

(2) The clearance rate was influenced mainly by the physical activity and local inflammation.

(3) The clearance rate increased in physically inactive subjects and in all pathological states except rheumatoid arthritis in the chronic stage.

(4) The clearance rate may be used to measure the degree of disease astivity and the effect of treatment in osteo-arthritis.

(5) The increased local blood flow induced by the neuro-vascular reflex is an important factor in determining the clearance rate.

The authors are grateful to Prof. N. Tsuyama and Assistant Prof. J. Matsumoto, University of Tokyo, for advice and encouragement.

This work was supported by a Science Grant from the Ministry of Edication.

\section{REFERENCES}

Ahlström, S., Gedda, P. O., and Hedberg, H. (1956). Acta rheum. scand., 2, 129 (Disappearance of radioactive serum albumin from joints in rheumatoid arthritis).

Barnett, C. H., Davies, D. V., and MacConaill, M.A. (1961). "Synovial Joints, Their Structure and Mechanics", p. 103. Longmans, London.

Bianchi, C. (1953). Brit. J. Pharmacol., 8, 130 (Experimental observation on a test for synovial permeability).

Davison, S., and Wisham, L. H. (1958). J. clin. Invest., 37, 389 (The clearance of $\mathrm{Na}^{24}$ from the normal and osteoarthritic knee joint and the response to intra-arterial Priscoline).

Ferguson, A. B., Jr., and Akahoshi, Y. (1960). J. Bone Jt Surg., 42-A, 617 (Vascular patterns in immobilized, denervated, or devascularized rabbit limbs).

- Waughan, L., and Ward, L. (1957). Ibid., 39-A, 583 (A study of disuse atrophy of skeletal muscle in the rabbit).

Fletcher, E. T. D. (1955). Cited by Barnett and others (1961).

Harris, R., Millard, J. B., and Banerjee, S. K. (1958). Ann. rheum. Dis., 17, 189 (Radiosodium clearance from the knee joint in rheumatoid arthritis).

Scholer, J. F., Lee, P. R., and Polley, H. F. (1959). Arthr. and Rheum., 2, 426 (The absorption of heavy water and radioactive sodium from the knee joint of normal persons and patients with rheumatoid arthritis).

Schröder, H., and Seyfarth, H. (1960). Z. Orthop., 93, 283 (Untersuchungen über die Durchblutung im Gipsverband). 
Seifter, J., and Baeder, D. H. (1954). Proc. Soc. exp. Biol. (N. Y.), 87, 276 (Technical factors influencing permeability of synovial membrane in rabbits).

,-- , and Begary, A. J. (1949). Ibid. 72, 277 (Influence of hyaluronidase and steroids on permeability of synovial membrane).

Sharp, G. W. G. (1963). Ann. rheum. Dis., 22, 50 (Effect of certain anti-arthritic compounds on the permeability of synovial membrane in the rabbit).

Udagawa, E. (1964). J. Jap. orthop. Ass., 38, 317 (Study on muscle atrophy of the thigh associated with arthritis of the knee joint. First report-On the haemodynamics of atrophied muscle). (Japanese).

\section{L'élimination de la phénolsulfonephtaléine de l'articulation du genou normal et pathologique}

RÉSUMÉ

(1) On étudia l'élimination de la phénolsulfonephtaléine de l'articulation du genou chez 31 sujets normaux et 37 porteurs d'une condition pathologique du genou.

(2) Le taux d'élimination était influencé surtout par l'activité physique et l'inflammation locale.

(3) Le taux d'élimination augmentait chez les sujets actifs physiquement et dans tous les états pathologiques à l'exception de l'arthrite rhumatismale au stade chronique.

(4) Le taux d'élimination est utile pour mesurer le degré de l'activité morbide et l'effet du traitement dans l'ostéoarthrose.

(5) La circulation sanguine locale augmentée provoquée par le reflexe neurovasculaire est un facteur important lorsqu'on détermine le taux d'élimination.
La eliminación de la fenolsulfonftaleina de la articulación de la rodilla normal y patológica

SUMARIO

(1) Se estudió la eliminación de la fenolsulfonftaleina de la articulación de la rodilla en 31 sujetos normales y 37 sujetos afectos de una condición patológica de la rodilla.

(2) La tasa de eliminación fué afectada principalmente por la actividad física y la inflamación local.

(3) La eliminación aumentaba en sujetos activos físicamente y en todos los estados patológicos, excepto en la artritis reumatoide en su estado crónico.

(4) La tasa de eliminación se puede emplear para medir el grado de la actividad morbosa y el efecto del tratamiento de la osteoartrosis.

(5) La circulación sanguinea local aumentada producida por el refiejo neurovascular es un factor importante en la determinación de la tasa de eliminación. 